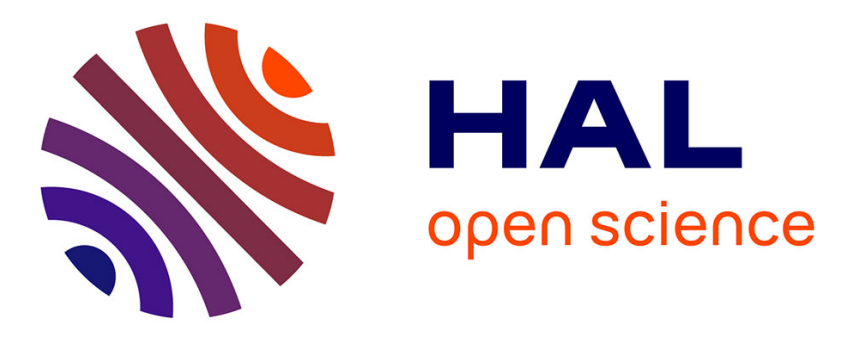

\title{
On the effect of gold nanoparticles loading within carbonaceous macro-mesocellular foams toward lithium-sulfur battery performances
}

Martin Depardieu, Rezan Demir-Cakan, Clément Sanchez, Marc Birot, Hervé Deleuze, Mathieu Morcrette, Rénal Backov

\section{To cite this version:}

Martin Depardieu, Rezan Demir-Cakan, Clément Sanchez, Marc Birot, Hervé Deleuze, et al.. On the effect of gold nanoparticles loading within carbonaceous macro-mesocellular foams toward lithium-sulfur battery performances. Solid State Sciences, 2016, 55, pp.112-120. 10.1016/j.solidstatesciences.2016.02.015 . hal-01291676

\section{HAL Id: hal-01291676 \\ https: / hal.sorbonne-universite.fr/hal-01291676}

Submitted on 21 Mar 2016

HAL is a multi-disciplinary open access archive for the deposit and dissemination of scientific research documents, whether they are published or not. The documents may come from teaching and research institutions in France or abroad, or from public or private research centers.
L'archive ouverte pluridisciplinaire HAL, est destinée au dépôt et à la diffusion de documents scientifiques de niveau recherche, publiés ou non, émanant des établissements d'enseignement et de recherche français ou étrangers, des laboratoires publics ou privés. 


\title{
On the effect of gold nanoparticles loading within carbonaceous
}

\section{macro-mesocellular foams toward lithium-sulfur battery performances}

\author{
Martin Depardieu, ${ }^{1,3}$ Rezan Demir-Cakan, ${ }^{2,6}$ Clément Sanchez, ${ }^{3}$ \\ Marc Birot ${ }^{4}$ Hervé Deleuze, ${ }^{4}$ Mathieu Morcrette ${ }^{2,5, *}$ and Rénal Backov ${ }^{1, *}$
}

${ }^{1}$ Univ. Bordeaux, Centre de Recherche Paul Pascal, UPR 8641 CNRS, F- 33600 Pessac, France.backov@crpp-bordeaux.cnrs.fr

${ }^{2}$ Laboratoire de Réactivité et Chimie des Solides, UMR 7314 CNRS, Université de Picardie Jules Verne, F- 80039 Amiens, France. mathieu.morcrette@u-picardie.fr

${ }^{3}$ Sorbonne Universités, UPMC Univ. Paris 06, CNRS, Collège de France, UMR 7574, Chimie de la Matière Condensée de Paris, F-75005, Paris, France.

${ }^{4}$ Univ. Bordeaux, Institut des Sciences Moléculaires, UMR 5255 CNRS, F-33405 Talence, France.

${ }^{5}$ RS2E, Réseau Français sur le Stockage Électrochimique de l'Énergie, FR CNRS 3459, France.

${ }^{6}$ Gebze Technical University, Department of Chemical Engineering, 41400 Gebze, Turkey. 


\begin{abstract}
Novel carbonaceous monolith foams loaded with gold nanoparticles have been synthesized and thoroughly characterized over several length scale. Their Li-S battery electrode capabilities have been assessed and compared while varying the gold loading and subsequently the specific surface area. Their capacities expressed in either mass $\left(\mathrm{mA} \mathrm{h} \mathrm{g}^{-1}\right)$ or volume $\left(\mathrm{mA} \mathrm{h} \mathrm{cm}^{-3}\right)$ dimensions have shown that specific surface area and nanoparticles loading are acting in a strong partitioning mode, rather than a cooperative mode, which does not favor the use of gold nanoparticles loading as efficient incremental path toward optimizing porous carbonaceous-based Li-S battery electrodes.
\end{abstract}

Keywords: Porous carbon; HIPE; Li-sulfide battery; Integrative chemistry; Gold nanoparticles 


\section{Introduction}

With the goals of minimizing air pollution and greenhouse gas emission while circumventing the issue of non renewable fossil energy, production of electric (EVs) and hybrid (HEVs) vehicles is the subject of intense research where social demand and needs have increased exponentially for the last twenty years. One problem that still must be overcome is their low autonomy compared to gas-based vehicles. There is thereby a crucial need for an efficient power source for electric engines that would reach the EV and HEV drastic targets in terms of energy density, safety and cost $[1,2]$. On one hand, sulfur cathode materials is of particular interest for EV battery applications as providing a theoretical capacity of $1675 \mathrm{~mA}$ $\mathrm{h} \mathrm{g}^{-1}$, around one magnitude higher than that of $\mathrm{LiFePO}_{4}$ cathodes (theoretical capacity of 176 $\mathrm{mA} \mathrm{h} \mathrm{g}^{-1}$ ) [3-6]. On the other hand, the Li/S system has not been yet integrated in EVs as a main penalty is the dissolution of sulfur that reacts with lithium metal, inducing a non stable insulating layer made of sulfur and $\mathrm{Li}_{2} \mathrm{~S}$ irreversibly deposited at both cathode and $\mathrm{Li}$ anode $[7,8]$. One way of fostering charge transport while constraining polysulfides at the cathode is to induce their confinement within conductive carbonaceous porous electrodes $[9,11]$. Also, in situ synthesized polysulfide species acting as original liquid cathodes have depicted better performances than conventional Li-S cell confinement configuration [12]. Particularly, the authors addressed the key role of the strength and porosity of the carbon electrode in the electrochemical properties and the detrimental formation of $\mathrm{Li}_{2} \mathrm{~S}$ at the porous carbon matrix. This approach has been extended in our group when conceiving monolithic carbonaceous foams having hierarchical porosity. In a study correlating the obtained capacity with the macrocellular foams porosity and surface area, the optimized foam exhibited the outstanding remnant capacity of around $1000 \mathrm{~mA} \mathrm{~h} \mathrm{~g}^{-1}$ after 50 cycles [13]. The issue of large volume change of the sulfur cathode during lithiation/delithiation in macroporous foams was also overcome. 
As said above, one penalty of the LiS batteries is the non-conducting nature of sulfur and low solubility of lithium polysulfide intermediates $\left(\mathrm{Li}_{2} \mathrm{~S}_{\mathrm{x}}, 4 \leq \mathrm{x} \leq 8\right)$. It is well known that noble metals, possessing high surface energy, present a strong affinity with sulfur atoms. Thereby, foams loaded with metallic nanoparticles could be interesting to promote polysulfides precipitation at the particles surface rather than at the carbon surface. Recently, we have combined meso-macroporous carbonaceous foams with gold and palladium loadings [14]. The bimodal porosity was offering sulfur confinement while accommodating the sulfur cathode large volume changes during lithiation/delithiation, and the metallic loading was promoting a better polysulfides anchoring at the cathode. The importance of metallic nanoparticles, $\mathrm{Au}$ in particular, for the stability of carbon-based electrodes during Li-S batteries cycling was thus demonstrated. In the present work, we focused on studying the effects of different metal loadings on the performances of these materials. The cooperative or partitioning action modes of mesoporosity and gold nanoparticles loading will be discussed while searching for the optimized scenario.

\section{Experimental section}

\subsection{Chemicals}

Tetradecyltrimethylammonium bromide $\left(\mathrm{C}_{14} \mathrm{H}_{29} \mathrm{~N}\left(\mathrm{CH}_{3}\right)_{3} \mathrm{Br}\right.$, TTAB, 98\%), was obtained from Alfa Aesar. Tetraethylorthosilicate ( $\mathrm{Si}(\mathrm{OEt})_{4}$, TEOS 99\%), dodecane (90\%), Synperonic $®$ P123 (poly\{ethylene glycol\}-block-poly\{propylene glycol\}-block-poly\{ethylene glycol\}) and potassium tetrachloroaurate $\left(\mathrm{KAuCl}_{4}\right)$ were purchased from Sigma-Aldrich. Hydrochloric acid (37\%) was purchased from Carlo Erba Reagents. Ablaphene RS101 (formophenolic prepolymer of the resol type in a hydroalcoholic solution) was purchased from Rhodia. All chemicals were used as received without further purification. 
The synthesis of the silica hard template by the combination of sol-gel chemistry and the concentrated emulsion technique was described previously [15]. Typically, TEOS (5 g) was added to an acidified TTAB solution (16 $\mathrm{g}$ of $35 \mathrm{wt} \%$ TTAB in water with $6 \mathrm{~g} \mathrm{HCl}$ ). The mixture was hand-stirred until it became transparent as TEOS was hydrolyzed. It was then transferred into a mortar and dodecane ( $35 \mathrm{~g}$ ) was added drop by drop while stirring slowly with a pestle. After the last added drop of dodecane, stirring was maintained for a few seconds to assure the concentrated emulsion homogeneity. This emulsion was then poured into polystyrene test tubes and left to rest for a week while the condensation reactions took place. At this stage, the tubes were either closed or put under a saturated water/ethanol atmosphere obtained with $100 \mathrm{~mL}$ of a 1:1 vol/vol water/ethanol solution in a $5 \mathrm{~L}$ dessicator. After condensation, the samples were immersed in a 1:1 vol/vol THF/acetone mix three times for $24 \mathrm{~h}$ to eliminate dodecane. Then, they were slowly dried in air at ambient temperature over a few days. After drying, the Si-HIPEs were calcinated at $650{ }^{\circ} \mathrm{C}$ for $6 \mathrm{~h}$ with a heating rate of 2 ${ }^{\circ} \mathrm{C} \min ^{-1}$ and a first plateau at $200{ }^{\circ} \mathrm{C}$ for $2 \mathrm{~h}$ to eliminate surfactant residues.

\subsection{Carbon foams synthesis (C-HIPE)}

The overall carbon foam synthetic pathway has already been described $[16,17]$. Typically, Si-HIPE monoliths were immersed in a beaker containing a solution composed of a 15:2:5 wt/wt mix of ethanol, P123 and phenolic resin respectively. The beaker was then placed in dessicator under dynamic vacuum until the effervescence, from the air removal from the silica foams, stopped. The system was then let under static vacuum for three days. After that, the samples were rapidly rinsed with ethanol, and then placed in an oven at $80{ }^{\circ} \mathrm{C}$ for 24 $\mathrm{h}$ to initiate resin polymerization. To complete the polymerization, a thermal treatment under air at $155{ }^{\circ} \mathrm{C}$ for $5 \mathrm{~h}$ was applied (heating rate of $2{ }^{\circ} \mathrm{C} \min ^{-1}$; first plateau at $80{ }^{\circ} \mathrm{C}$ for $12 \mathrm{~h}$; second plateau at $110{ }^{\circ} \mathrm{C}$ for $3 \mathrm{~h}$ ). Pyrolysis was performed under argon at $900{ }^{\circ} \mathrm{C}$ for $1 \mathrm{~h}$ (heating rate of $4{ }^{\circ} \mathrm{C} \mathrm{min}^{-1}$ with a plateau at $350{ }^{\circ} \mathrm{C}$ for $30 \mathrm{~min}$ to eliminate the copolymers 
before pyrolysis). Finally, silica hard template was removed by washing with a $10 \mathrm{wt} \% \mathrm{HF}$ solution for $24 \mathrm{~h}$ and rinsing three times for $24 \mathrm{~h}$ in distilled water. The obtained carbon foam is thereafter named C-HIPE $(2 \mathrm{P} 5 \mathrm{HF})$.

\subsection{Gold nanoparticles heterogeneous nucleation}

C-HIPE ${ }_{(2 \mathrm{P} 5 \mathrm{HF})}$ monoliths were put in beakers containing $0.01 \mathrm{M}, 0.02 \mathrm{M}, 0.03 \mathrm{M}, 0.04 \mathrm{M}$, and $0.05 \mathrm{M}$ solutions of $\mathrm{KAuCl}_{4}$ in a $1: 1 \mathrm{vol} / \mathrm{vol}$ acetone/water mix. The beakers were put under dynamic vacuum until effervescence stopped, and then left under static vacuum for three days. The samples were dried in air, then $\mathrm{KAuCl}_{4}$ was reduced into metallic gold by a thermal treatment at $80{ }^{\circ} \mathrm{C}$ under $0.8 \mathrm{MPa}$ of $\mathrm{H}_{2}$. Final elemental analyses over the samples have shown a gold loading increase $2.5,6.2,9.2,9.7$ and $11.5 \mathrm{wt} \%$, while increasing the starting molar concentration of the $\mathrm{KAuCl}_{4}$ solutions as depicted above. The samples are thereafter named according to their gold content: 3-Au@C-HIPE ${ }_{(2 \mathrm{P} 5 \mathrm{HF})}, 6-\mathrm{Au} @ \mathrm{C}-\mathrm{HIPE} \mathrm{E}_{(2 \mathrm{P} 5 \mathrm{HF})}, 9-\mathrm{Au} @$ $\mathrm{C}-\mathrm{HIPE}_{(2 \mathrm{P} 5 \mathrm{HF})}, 10-\mathrm{Au} @ \mathrm{C}-\mathrm{HIPE} \mathrm{E}_{(2 \mathrm{P} 5 \mathrm{HF})}$, and 12-Au@C-HIPE ${ }_{(2 \mathrm{P} 5 \mathrm{HF})}$.

\subsection{Li-S batteries preparation}

Electrolyte solution used in this study was $1 \mathrm{M}$ lithium bis(trifluoromethanesulfonyl)imide (LiTFSI) in tetramethylene sulphone (TMS). $\mathrm{Li}_{2} \mathrm{~S}_{6}$ was chemically synthesized by reacting stoichiometric amounts of sulfur and lithium in ethylene glycol diethyl ether at $150{ }^{\circ} \mathrm{C}$. A precise amount of active material $\mathrm{Li}_{2} \mathrm{~S}_{6}$ was dissolved in the electrolyte and caution was taken to introduce a very precise quantity of electrolyte in the cell. For each electrode the mass of carbon foam and $\mathrm{Li}_{2} \mathrm{~S}_{6}$ are the same. Carbon foams were very smoothly grinded in order to keep the porosity.

\subsection{Characterizations}

Scanning electron microscopy (SEM) observations were performed in a Hitachi TM-1000 apparatus at $15 \mathrm{kV}$. The specimens were sputtered with $\mathrm{Au} / \mathrm{Pd}$ in a vacuum evaporator prior to examination. High-resolution transmission electron microscopy (HR-TEM) micrographs 
were obtained with a Jeol 2200 FS microscope. The carbonaceous powders were deposited on a copper grid coated with a Formvar/carbon membrane. Surface areas and pore characteristics on a micro-(meso)scale were obtained with a Micromeritics ASAP 2010 nitrogen sorption analyzer. To get the macrocellular characteristics, intrusion/extrusion mercury measurements were performed in a Micromeritics Autopore IV 9500 porosimeter with the following parameters: contact angle $=130^{\circ}$, mercury surface tension $=485 \mathrm{mN} \mathrm{m}^{-1}$, maximum intrusion pressure $=124 \mathrm{MPa}$. X-ray diffraction curves were acquired using a Bruker D8 diffractometer $\left(\mathrm{Cu} \mathrm{K} \mathrm{K}_{\alpha}\right.$ radiation, $\left.\lambda=1.54056 \AA\right)$ equipped with a position sensitive detector (PSD). Galvanostatic and potentiostatic cycling measurements were performed with a classical two-electrode Swagelok-type ${ }^{\mathrm{TM}}$ cell using $0.1 \mathrm{~mL}$ electrolyte with $\mathrm{C} / 10$ current densities, voltage range between 1.0-3.0 V vs Li, with a VMP3 apparatus (Bio-logic, France). Gold content has been addressed by flame spectrophotometry.

\section{Results and discussion}

Due to their chemical inertness, high surface area and electronic conductivity, when at least partially graphitized, porous carbonaceous materials appear as relevant candidates for a wide scope of applications ranging from water and air purification, adsorption to electrocatalysis, energy storage and conversion $[18,19]$. Beyond tuning the microstructure, the rational shaping of such porous materials at various dimension scales is also of first importance and relies on either hard or soft templating synthetic paths where void space morphologies and pore size distributions can be tuned with a certain versatility. Micro-, meso and macropores can be simultaneously present within the materials, hence the notion of hierarchical porosity. Indeed, this hierarchical porosity is at first glance very important for applications where molecular reactivity and mass transport have to be optimized. According to IUPAC, microporosity depicts pores with diameter $<2 \mathrm{~nm}$, mesopores lie between $2 \mathrm{~nm}$ 
and $50 \mathrm{~nm}$ while all diameters above $50 \mathrm{~nm}$ are considered as macroporosity. Indeed, this classification of pore sizes is highly related to the fluid hydrodynamics occurring at each level [20]. At the micropore length scale, the fluid motion is driven only by diffusion where convection is negligible. At the macropore length scale, it is based on convection only where diffusion is negligible considering the whole mass transport. It is basically the Poiseuille law (when fluid are Newtonian). At the mesopore length scale, the hydrodynamics are hybrid. The scenario can be depicted as a fluid moving through convection in which molecules are diffusing, this behavior being known as dispersion. This is the reason why a hierarchical porosity from macropores (optimizing the mass transport) to micropores (where molecular reactivity occurs) is of importance for catalysis or energy conversion/storage applications. In this plan of shaping porosity over "all length scales", one route makes use of pre-existing hard template [21] impregnated with a carbon source being subsequently carbonized/graphitized. After vanishing the hard template, a negative carbonaceous replica is obtained. In this specific context, we have proposed recently generation of carbonaceous micro-macroporous [16] and meso-macroporous [17] monolithic foams using silica-HIPE [15] as exo-templating matrices, HIPE being the acronym for High Internal Phase Emulsion [22-25].

Using this synthetic path, gold- loaded carbonaceous foams can be obtained with a texture that resembles aggregated hollow spheres, as observed before [13-16] (Fig. 1).

\section{Insert figure 1 here}

Fig. 1. SEM micrograph of a typical 12-Au@C-HIPE $(2 \mathrm{P} 5 \mathrm{HF})$ sample. Insert: photography of a typical monolithic $12-\mathrm{Au} @ \mathrm{C}-\mathrm{HIPE}_{(2 \mathrm{P} 5 \mathrm{HF})}$ sample. Scale is in centimeters. Extracted from reference 14 (RSC).

Beyond SEM observations, mercury porosimetry characterizes pore size distribution and foams' bulk and skeleton densities. Concerning the pore size distribution, we would like to recall that the diameter assessed by mercury porosimetry is the dimension that minimizes the mercury infiltration within the foams, this to say the diameter of windows that connect 
adjacent cells and not the cell diameter itself. Pore size distributions are provided within Fig.

2.

\section{Insert Figure 2 here}

Fig. 2. Windows size distributions drawn from mercury porosimetry measurements. a) 2P5HF b) 3-Au@C-HIPE $(2 \mathrm{P} 5 \mathrm{HF})$ c) 6-Au@C-HIPE $(2 \mathrm{P} 5 \mathrm{HF})$ d) 9-Au@C-HIPE $\mathrm{(2P5HF}_{2}$ e) 10-Au@C$\mathrm{HIPE}_{(2 \mathrm{P} 5 \mathrm{HF})}$ f) 12-Au@C-HIPE $(2 \mathrm{P} 5 \mathrm{HF})$.

Objectively, we can say that the effect of the gold loading over the windows diameter distribution is completely negligible. Basically, we can state that the windows diameters are polydisperse and vary from 1 to $12 \mu \mathrm{m}$ for the majority of population, distribution being squeezed within the 1-6 $\mu \mathrm{m}$ range. The second information provided by mercury porosimetry are the foam bulk and skeleton densities. The results are summarized within the Table 1.

Table 1. Foams characteristics obtained by mercury porosimetry. *Values from references 13 , 14 (RSC).

\section{Insert table 1 here}

As expected, the intrusion volume is decreasing while increasing the amount of gold loading within the carbon foams. Also totally expected, both skeleton and bulk densities are increasing when the gold content is increased.

The micro- and mesoporosity were explored with nitrogen physisorption experiments. The isotherms are displayed in Fig. 3, while the mesoscopic characteristics are summarized within the Table 2.

\section{Insert Figure 3 here}

Fig. 3. Adsorption (black) and desorption (red) isotherms obtained from nitrogen physisorption data. a) C-HIPE $(2 \mathrm{P} 5 \mathrm{HF})$ b) 3-Au@C-HIPE ${ }_{(2 \mathrm{P} 5 \mathrm{HF})}$ c) 6-Au@C-HIPE $\mathrm{E}_{(2 \mathrm{P} 5 \mathrm{HF})}$ d) 9$\left.\mathrm{Au} @ \mathrm{C}-\mathrm{HIPE}_{(2 \mathrm{P} 5 \mathrm{HF})} \mathrm{e}\right) 10-\mathrm{Au} @ \mathrm{C}-\mathrm{HIPE}_{(2 \mathrm{P} 5 \mathrm{HF})}$ f) 12-Au@C-HIPE $(2 \mathrm{P} 5 \mathrm{HF})$. 
The adsorption-desorption isotherms are composite of type I and IV, characteristic of micro/mesoporous materials. Considering either the volume adsorbed (Fig. 3) or the BET surface area (Table 2), we can notice that both are decreasing when increasing the gold loading. At first glance, this trend is expected as both volume and surface area are expressed per mass of media.

Table 2. Foams characteristics obtained nitrogen physisorption measurements. *Values from references 13,14 (RSC).

\section{Insert Table 2 here}

However, when examining the volumes adsorbed at low relative pressure, that relies on microporosity exclusively, we can see that these values are diminishing drastically from almost $200 \mathrm{~cm}^{3} \mathrm{~g}^{-1}$ (Fig. 3a) to $42 \mathrm{~cm}^{3} \mathrm{~g}^{-1}$ (Fig. 3f), i.e. a decrease of 80\%. Looking at the same samples, the volume adsorbed apart from the microporosity is decreasing of only $50 \%$, from $100 \mathrm{~cm}^{3} \mathrm{~g}^{-1}$ to $50 \mathrm{~cm}^{3} \mathrm{~g}^{-1}$. Whereas the increase in density induced by the gold loading should hamper equivalently the micro- and the mesoscopic void spaces, it is not the case here. Thereby, the increasing density is not the only parameter involved. We must consider that gold particles will probably minimize the nitrogen diffusion through the porosity, the more nanoparticles will be present, the higher the effect over minimizing nitrogen diffusion through the voids will be. Still at the mesoscopic length scale, it is important to assess the gold particles size and associated population while increasing the loading. We had earlier generated gold nanoparticles in various meso-macrocellular foams, here we focused on the carbonaceous host that possessed previously the highest capacity and capacity retention, while varying the amount of gold loading. The first issue is to address the metallic zerovalent nature of gold while assessing the fact that all the starting $\mathrm{Au}^{\mathrm{III}}$ has been reduced. The tool of choice here is X-ray photoelectron spectroscopy (XPS) and a typical XPS spectrum is provided 
within the supplemental (Fig. S1). In Fig. $\mathrm{S} 1$ the $\mathrm{Au} 4 \mathrm{f}_{7 / 2}$ and $4 \mathrm{f}_{5 / 2}$ peaks at 83.6 and $87.5 \mathrm{eV}$ respectively demonstrate without ambiguity the full reduction of the gold salt into zerovalent metallic gold [26-29]. Also, TEM micrographs of representative gold nanoparticles can be seen in Fig. 4.

\section{Insert Figure 4 here}

Fig. 4. a) TEM micrographs for a) 3-Au@C-HIPE $E_{(2 \mathrm{P} 5 \mathrm{HF})}$ and b) $10-\mathrm{Au} @ \mathrm{C}-\mathrm{HIPE}(2 \mathrm{P} 5 \mathrm{HF})$.

Clearly, the particle size distributions are polydisperse. Of course, gold particles generated with high concentrations of $\mathrm{KAuCl}_{4}$ have larger diameters than those obtained with low amounts of gold salt. Indeed, everything relies on the nucleation-growth balance. At low concentration of gold salt, the micropores present at the surface of the macropores walls will act as defects where the nucleation enthalpy is minimized. In that scenario, the nucleation events will be high while growth will be minimized, leading to small-sized particles associated with a narrow distribution of particle diameters (Fig. 4a). This scenario is the same to what occurred for $\mathrm{LiBH}_{4}$ heterogeneous nucleation within such carbonaceous micromacrocellular foams [30]. In this vein, when the starting gold salt concentration is reaching high values, the nucleation events will be minimized while growth will be optimized, leading to bigger particles (Fig. 4b) associated with a broad size distribution. In order to get better quantitative results, several TEM and HR-TEM micrographs were mathematically analyzed to roughly estimate the distributions of particles diameters. When looking at the results shown in Fig. 5, the overall scenario of nucleation-growth balance is still valid. For instance, for the materials 3-Au@C-HIPE $(2 \mathrm{P} 5 \mathrm{HF}), \quad 6-\mathrm{Au} @ \mathrm{C}-\mathrm{HIPE}_{(2 \mathrm{P} 5 \mathrm{HF})}$ and $\quad 9-\mathrm{Au} @ \mathrm{C}-\mathrm{HIPE}_{(2 \mathrm{P} 5 \mathrm{HF})} \quad$ the distributions of particle sizes are ranging from 1.5 to $10 \mathrm{~nm}$ (Fig. 5a-c). For materials 10$\mathrm{Au} @ \mathrm{C}-\mathrm{HIPE}_{(2 \mathrm{P} 5 \mathrm{HF})}$ and 12-Au@C-HIPE $\mathrm{(2P5HF)}$, the particle sizes distributions are broader (1.5 to $30 \mathrm{~nm}$ ) with sizes drastically above $10 \mathrm{~nm}$, which was not the case with the former materials. Interestingly, the plot of the density of particles per surface area $\left(1000 \mathrm{~nm}^{2}\right) v s$. the 
gold weight percentage (Fig. 5f) shows clearly that, up to $9 \mathrm{wt} \%$, the number of particles per $1000 \mathrm{~nm}^{2}$ is increasing with the gold $\mathrm{wt} \%$. In this domain of concentrations, the nucleation events prevail toward the growth process. Above $9 \mathrm{wt} \%$, the number of particles is drastically decreased (Fig. 5f) while the particle sizes are now acquiring high values (Fig. 5e,d), meaning that here the nucleation events are minimized but the particles growth is optimized.

\section{Insert Figure 5 here}

Fig. 5. Size distribution of gold nanoparticles for each gold loading: a) $3 \%$ b) $6 \%$ c) $9 \%$ d) $10 \%$ e) $12 \%$ and f) number of gold nanoparticles observed for $1000 \mathrm{~nm}^{2}$ in TEM pictures as a function of gold loading in samples.

The electrochemical cycling of the different Au@C-HIPE $\mathrm{E}_{(2 \mathrm{P} 5 \mathrm{HF})}$ foams are shown in Fig. 6. At first glance the results are quite deceiving when compared with the $\mathrm{C}-\mathrm{HIPE}_{(2 \mathrm{P} 5 \mathrm{HF})}$ material free of metal loading (Fig. 6a), for which $2 \mathrm{Li}$ are exchanged, a result close to the theoretical capacity. When varying the gold loading, the number of $\mathrm{Li}$ exchanged varies from around $1 \mathrm{Li}$ for $12-\mathrm{Au} @ \mathrm{C}-\mathrm{HIPE}_{(2 \mathrm{P} 5 \mathrm{HF})}$ to below 1.5 for the other gold-loaded carbonaceous foams.

\section{Insert Figure 6 here}

Fig. 6. Charge-discharge profiles of $1 \mathrm{M} \mathrm{Li}_{2} \mathrm{~S}_{6}$ in TMS with different carbon electrodes. a) C$\mathrm{HIPE}_{(2 \mathrm{P} 5 \mathrm{HF})}$ b) 3-Au@C-HIPE ${ }_{(2 \mathrm{P} 5 \mathrm{HF})}$ c) 6-Au@C-HIPE ${ }_{(2 \mathrm{P} 5 \mathrm{HF})}$ d) 9-Au @C-HIPE ${ }_{(2 \mathrm{P} 5 \mathrm{HF})}$ e) 10Au@C-HIPE $E_{(2 \mathrm{P} 5 \mathrm{HF})}$ f) 12-Au@C-HIPE $(2 \mathrm{P} 5 \mathrm{HF})$. (a) Extracted from ref 13.

More precisely, we can notice that the reversible capacity decreases when increasing the gold loading up to $9 \mathrm{wt} \%$ (Fig. 6d), then this reversible capacity starts to increase for the materials 10-Au@C-HIPE $E_{(2 \mathrm{P} 5 \mathrm{HF})}\left(\right.$ Fig. 6e) and 12-Au@C-HIPE ${ }_{(2 \mathrm{P} 5 \mathrm{HF})}$ (Fig. 6f). Thus, a crossover of the capacity losses is appearing at $9 \mathrm{wt} \%$ gold loaded. At that stage the remaining question is why the gold nanoparticles would affect the $\mathrm{Li}_{2} \mathrm{~S}$ nucleation and growth, $\mathrm{Li}_{2} \mathrm{~S}$ acting as an in situ growing passivation layer that minimizes the reversible capacity? 
A first argument that might be important is that the carbon walls and the metallic nanoparticles possess different surface energies, and thereby different wettabilities toward $\mathrm{Li}_{2} \mathrm{~S}$ solutes. The main criteria that governs wettability is the spreading " $\mathrm{S}$ " parameter, indicating that the spreading of a liquid on a solid surface is favored if this liquid is less polarizable than the solid [30]. This is the so-called "wetting criteria" addressed by the Zisman rule [31]. We have already taken benefit of differences in surface polarizability between carbon materials (holding surface heteroatoms, mostly oxygen) [16,17] and metallic nanoparticles to induce specific wetting of $\mathrm{LiBH}_{4}$ solution on metallic nanoparticles, offering thereby advantageous cyclable hydrogen storage properties [14] when compared with carbon foams free of metal loading [32]. So we can expect $\mathrm{Li}_{2} \mathrm{~S}$ to grow preferentially on the surface of gold particles.

The second important point is that we know from the porosity evaluation that the gold loading is associated with a locking of the accessible mesoporosity. So, the first conclusion is that $\mathrm{Li}_{2} \mathrm{~S}$ will preferentially grow on the gold surface that is limiting the access to mesoporosity, hence reducing the reversible capacity. However, if we look at the particle size distributions (Fig. 5), we can see that the cross-over of capacity losses at 9 wt\% gold loading corresponds to the limit configuration where particle size distribution is squeezed between 1.5 $\mathrm{nm}$ to $12 \mathrm{~nm}$ and not extended at higher diameters as it is the case when 10 and $12 \mathrm{wt} \%$ goals loading are reached. With smaller gold nanoparticles (up to $9 \mathrm{wt} \%$ ) the whole gold specific surface area will be higher than the case where bigger nanoparticles are appearing (10 and 12 $\mathrm{wt} \%$ ), thereby offering higher surface for $\mathrm{Li}_{2} \mathrm{~S}$ heterogeneous nucleation.

The capacity retention upon cycling and the normalized capacity vs. the gold loading are provided in Fig. 7. Table 3 summarized the initial and reversible gravimetric and volumetric capacities. 


\section{Insert Figure 7 Here}

Fig. 7. a) Fraction of initial capacity remaining as a function of the number of cycles. b) Initial volumic (circle) and massic (square) capacities as a percentage of C-HIPE ${ }_{(2 \mathrm{P} 5 \mathrm{HF})}$ initial capacity $v s$. the gold loading within the carbon matrices.

The consequence of the insulating $\mathrm{Li}_{2} \mathrm{~S}$ formation is also observable in Fig. 7 a that depicts the metal-loaded carbonaceous foams gravimetric capacity $v s$. the number of cycles. When cycling, contrary to the matrix free of gold, the capacity retention decreases very fast for the first 25 cycles, after what the decreasing slope is moderated. Regardless of the gold loading, the slope of the decreasing gravimetric capacity after 30 cycles is roughly the same.

Considering the Fig. $7 \mathrm{~b}$ and Table 3, we can notice a strong decrease of the initial gravimetric capacity when adding gold nanoparticles, going from $1680 \mathrm{~mA} \mathrm{~h} \mathrm{~g}^{-1}$ to $819 \mathrm{~mA} \mathrm{~h}$ $\mathrm{g}^{-1}$ for the C-HIPE $(2 \mathrm{P} 5 \mathrm{HF})$ and 12-Au@C-HIPE $(2 \mathrm{P} 5 \mathrm{HF})$ foams respectively (Table 3), the trend being the same for the remnant gravimetric capacity after 50 cycles. Overall, we can say that adding gold nanoparticles is limiting strongly the initial gravimetric capacity up to around $50 \%$ (see Table 3). It means that for the gravimetric capacity the loss of specific surface area due to the increasing of the gold loading (Table 2) is not compensated by the higher affinity between the gold nanoparticles and $\mathrm{Li}_{2} \mathrm{~S}$ species, meaning a partitioning action mode between specific surface area and gold loading toward the Li/S battery performances.

This study raises a very important point that needs to be stressed: without gold nanoparticles, mesoporosity is fully accessible and reversibility upon cycling is better. At high amount of gold, the reversible capacity is increased but not the capacity retention, meaning that much mesoporosity is needed rather than additives that help $\mathrm{Li}_{2} \mathrm{~S}$ precipitation. If considering the behavior of foams with nanoparticles only, two domains exist (Fig. 7b dashed lines). A first one where the initial gravimetric capacity is increasing when increasing the gold loading up to $9.7 \mathrm{wt} \%$, corresponding to the foam 10-Au@C-HIPE $(2 \mathrm{P} 5 \mathrm{HF})$, followed by a decrease of the gravimetric capacity for the foam 12-Au@C-HIPE $(2 \mathrm{P} 5 \mathrm{HF})$. In the first region 
the increase of the gold loading is circumventing the loss of surface area (Table 2), while in the region above $9.7 \mathrm{wt} \%$ gold the increasing gold loading does not compensate any more the loss of surface area, which signifies again that surface area and gold loading are acting in a partitioning manner rather than a cooperative one.

We express the capacities in both volumetric and gravimetric dimensions because with porous materials as battery electrodes it is important to normalize the capacity not only according to the mass of polysulfide as guest but also to the volume of the carbonaceous host. Indeed, one has to consider that if reaching high gravimetric capacity the volume of the electrodes has to be over-expressed, then the overall real input has to be averaged while considering both parameters dealing with energy conversion.

Table 3. Carbon foams volumetric and gravimetric capacities, initial and after 50 cycles.

\section{Insert Table 3 here}

Concerning the initial volumetric capacity (Table 3), we can see that the differences between the carbon foams are squeezed, going from $202 \mathrm{~mA} \mathrm{~h} \mathrm{~g}$ to $147 \mathrm{~mA} \mathrm{~h} \mathrm{~g}{ }^{-1}$ respectively for the $\mathrm{C}-\mathrm{HIPE}_{(2 \mathrm{P} 5 \mathrm{HF})}$ and 12-Au@C-HIPE $\mathrm{(2P5HF)}$ foams. Particularly, the starting volumetric capacity of the $\mathrm{C}-\mathrm{HIPE}_{(2 \mathrm{P} 5 \mathrm{HF})}$ material and the $10-\mathrm{Au} @ \mathrm{C}-\mathrm{HIPE}_{(2 \mathrm{P} 5 \mathrm{HF})}$ are now comparable, respectively 202 and $187 \mathrm{~mA} \mathrm{~h} \mathrm{~cm}^{-3}$. Their loss of volumetric capacity after 50 cycles is also quite similar, around $25 \%$ (Table 3 ). Again, the volumetric capacity of the carbon electrodes with gold nanoparticles increases up to $9.7 \mathrm{wt} \%$ of gold loading, corresponding to the material 10-Au@C-HIPE $(2 \mathrm{P} 5 \mathrm{HF})$. Above $9.7 \mathrm{wt} \%$, the volumetric capacity collapses for the material 12-Au@ C-HIPE $(2 \mathrm{P} 5 \mathrm{HF})$.

Overall, considering both volumetric and gravimetric capacities, and the fact that gold nanoparticles loading and specific surface area are not operating cooperatively but rather in a 
partitioning mode, the use of gold nanoparticles to promote discrete nucleation and growth of polysulfide intermediate is not efficient toward optimizing Li-S battery electrodes efficiency.

\section{Conclusions}

The insulating nature of sulfur and the low solubility of lithium polysulfide intermediates penalize the Li-S batteries. To circumvent the formation of a continuous passivation layer at the surface of the electrodes is to promote the preferential and discrete nucleation and growth of polysulfide intermediates on gold nanoparticles loaded within the carbonaceous foams. We have shown that increasing the gold nanoparticles loading is inducing a strong decrease of the foams specific surface area. Thereby, the Li-S battery electrode capabilities have been scrutinized and compared while varying the gold loading and subsequently the specific surface area. Considering the capacities expressed in gravimetric $\left(\mathrm{mA} \mathrm{h} \mathrm{g}^{-1}\right)$ and volumetric $\left(\mathrm{mA} \mathrm{h} \mathrm{cm}^{-3}\right)$ dimensions we found out that specific surface area and gold nanoparticles loading are acting through a strong partitioning mode, rather than a cooperative one. This partitioning action mode is not pleading for the use of gold nanoparticles loading as efficient incremental path toward optimizing porous carbonaceousbased Li-S battery electrodes. 


\section{References}

[1] Armand M, Tarascon JM. Building better batteries. Nature 2008;451:652-657.

[2] Agostini M, Aihara Y, Yamada T, Scrosati B, Hassoun J. A lithium-sulfur battery using a solid, glass-type $\mathrm{P}_{2} \mathrm{~S}_{5}-\mathrm{Li}_{2} \mathrm{~S}$ electrolyte. Solid State Ionics 2013;224:48-51.

[3] Akridge JR, Mikhaylik YV, White N. Li/S fundamental chemistry and application to high-performance rechargeable batteries. Solid State Ionics 2004;175:243-245.

[4] Cheon SE, Choi SS, Han JS, Choi YS, Jung BH, Lim HS. Capacity fading mechanisms on cycling a high-capacity secondary sulfur cathode. $\mathbf{J}$ Electrochem Soc 2004;151:A2067-A2073.

[5] Yamin H, Gorenshtein A, Penciner J, Sternberg Y, Peled E. Oxidation/reduction mechanisms of polysulfides in THF solutions. J Electrochem Soc 1988;135:1045-1048.

[6] Kang, K, Meng, YS, Breger, J, Grey, CP, Ceder, G. Electrodes with high power and high capacity for rechargeable lithium batteries. Science 2006;311:977-980.

[7] Herbert D, Ulam J. Electric dry cells and storage batteries. US patent 3043896, 1962.

[8] Elazari R, Salitra G, Taylosef Y, Grinblat J, Scordilis-kellay C, Xiao A, et al. Morphological and structural studies of composite sulfur electrodes upon cycling by HRTEM, AFM and Raman spectroscopy. J Electrochem Soc 2010;157:A1131-A1138.

[9] Ji X, Lee KT, Nazar LF. Nature Mater 2009;8:500.

[10] Wang H, Yang Y, Liang Y, Robinson JT, Li Y, Jackson A, et al. Graphene-wrapped sulfur particles as a rechargeable lithium-sulfur battery cathode material with high capacity and cycling stability. Nano Lett 2011;2644-2647.

[11] Evers S, Yim T, Nazar LF. Understanding the nature of absorption/adsorption in nanoporous polysulfide sorbents for the Li-S battery. J Phys Chem C 2012;116:1965319658. 
[12] Demir-Cakan R, Morcrette M, Guéguen A, Dedryvère R, Tarascon JM. Li-S batteries: simple approaches for superior performance. Energy Environ Sci 2013;6:176-182.

[13] Depardieu M, Janot R, Sanchez C, Bentaleb A, Gervais C, Birot M, et al. Carbonaceous multiscale-cellular foams as novel electrodes for stable, efficient lithium-sulfur batteries. RSC Advances 2014;4:23971-23976.

[14] Depardieu M, Morcrette M, Sanchez C, Birot M, Janot R, Gervais-Stary C, et al. Novel Au/Pd@carbon macrocellular foams as electrodes for lithium-sulfur batteries. J Mater Chem A 2014;2:18047-18057.

[15] Carn F, Colin A, Achard MF, Deleuze H, Birot M, Backov R. Inorganic monoliths hierarchically textured via concentrated direct emulsion and micellar templates. J Mater Chem 2004;14:1370-1376.

[16] Brun N, Prabaharan SRS, Morcrette M, Sanchez C, Pécastaing G, Derré A, et al. Hard macrocellular silica $\mathrm{Si}(\mathrm{HIPE})$ foams templating micro/macroporous carbonaceous monoliths: applications as lithium ion battery negative electrodes and electrochemical capacitors. Adv Funct Mater 2009;19:3136-3145.

[17] Brun N, Prabaharan SRS, Morcrette M, Deleuze H, Birot M, Babot O, et al. Design of hierarchical porous carbonaceous foams from a dual-template approach and their use as electrochemical capacitor and $\mathrm{Li}$ ion battery negative electrodes. J Phys Chem $\mathrm{C}$ 2012;116:1408-1421.

[18] Foley HC. Carbogenic molecular sieves: synthesis, properties and applications. Microporous Mater 1995;4:407-433.

[19] Kyotani T. Control of pore structure in carbon. Carbon 2000;38:269-286.

[20] Guyon E, Hulin JP, Petit L, Mitescu CD. In Physical Hydrodynamics, Oxford University Press (2001). 
[21] Schüth F. Endo- and exotemplating to create high-surface-area inorganic materials. Angew Chem Int Ed 2003;42:3604-3622.

[22] Barby D, Haq Z. Low density porous cross-linked polymeric materials and their preparation. European patent 0060138, 1982.

[23] Cameron NR, Sherrington DC. High Internal Phase Emulsions (HIPEs) Structure, properties and use in polymer preparation in Advances in Polymer Science, Eds Springer Berlin / Heidelberg, 1996;126:163.

[24] Cameron N. High internal phase emulsion templating as a route to well-defined porous polymers. Polymer 2005;46:1439-1449.

[25] Zhang H, Cooper AI. Synthesis and applications of emulsion-templated porous materials. Soft Matter 2005;2:107-113.

[26] Brun M, Berthet A, Bertolini JC. XPS, AES and Auger parameter of Pd and PdO. J Electron Spectrosc Relat Phenom 1999;104:55-60.

[27] Regev O, Backov R, Faure C. Gold nanoparticles spontaneously generated in oniontype multilamellar vesicles. bilayers-particle coupling imaged by cryo-TEM. Chem Mater 2004;16:5280-5285.

[28] Féral-Martin C, Birot M, Deleuze H, Desforges A, Backov R. Integrative chemistry toward the first spontaneous generation of gold nanoparticles within macrocellular polyHIPE supports (Au@polyHIPE) and their application to eosin reduction. React Funct Polym 2007;67:1072-1082.

[29] Tunc I, Suzer S, Correa-Duarte MA, Liz-Marzán LM. XPS characterization of Au (core)/SiO 2 (shell) nanoparticles. J Phys Chem B 2005;109:7597-7600.

[30] de Gennes PG, Brochar-Wyart F. Quéré D. in "Gouttes, bulles, perles et ondes", collection échelles, Belin Edition 2005. 
[31] Zisman, W. in "Contact angle wettability and adhesion", Chemical series, 1964, 43, Washington.

[32] Fox, J, Zisman, W. The spreading of liquids on low energy surfaces. I. polytetrafluoroethylene. J Colloid Interface Sci 1950;5:514-531.

[33] Brun N, Janot R, Gervais C, Morcrette M, Deleuze H, Sanchez C, et al. Preparation of $\mathrm{LiBH}_{4} @$ carbon micro-macrocellular foams: tuning hydrogen release through varying microporosity. Energy Environ Sci 2010, 3, 824-830. 


\title{
On the effect of gold nanoparticles loading within carbonaceous
}

\section{macro-mesocellular foams toward lithium-sulfur battery performances}

\author{
Martin Depardieu, ${ }^{1,3}$ Rezan Demir-Cakan, ${ }^{2,6}$ Clément Sanchez, ${ }^{3}$ \\ Marc Birot, ${ }^{4}$ Hervé Deleuze, ${ }^{4}$ Mathieu Morcrette ${ }^{2,5,}$ and Rénal Backov ${ }^{1, *}$
}

${ }^{1}$ Univ. Bordeaux, Centre de Recherche Paul Pascal, UPR 8641 CNRS, F- 33600 Pessac, France.backov@crpp-bordeaux.cnrs.fr

${ }^{2}$ Laboratoire de Réactivité et Chimie des Solides, UMR 7314 CNRS, Université de Picardie Jules Verne, F- 80039 Amiens, France. mathieu.morcrette@u-picardie.fr

${ }^{3}$ Sorbonne Universités, UPMC Univ. Paris 06, CNRS, Collège de France, UMR 7574, Chimie de la Matière Condensée de Paris, F-75005, Paris, France.

${ }^{4}$ Univ. Bordeaux, Institut des Sciences Moléculaires, UMR 5255 CNRS, F-33405 Talence, France.

${ }^{5}$ RS2E, Réseau Français sur le Stockage Électrochimique de l'Énergie, FR CNRS 3459, France.

${ }^{6}$ Gebze Technical University, Department of Chemical Engineering, 41400 Gebze, Turkey.

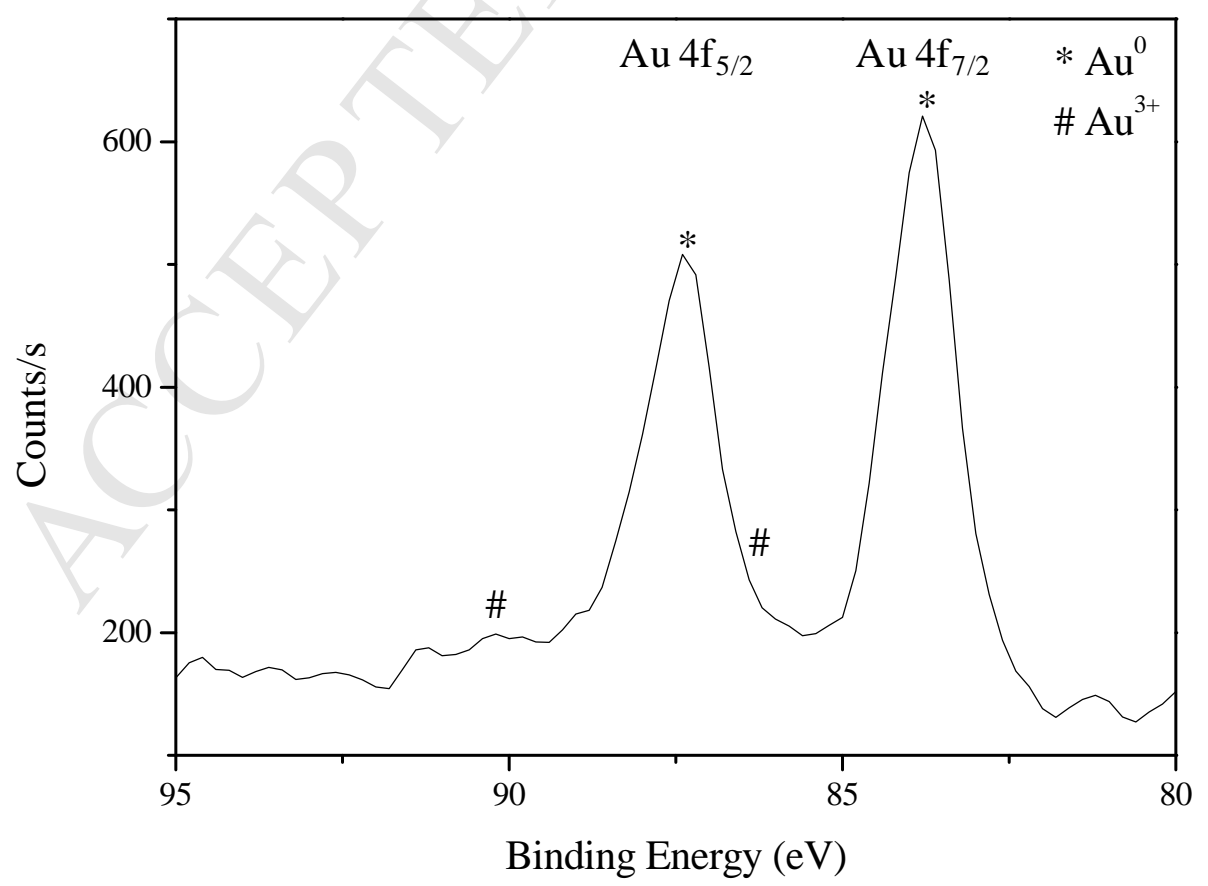

Figure S1. XPS analysis of the 10-Au@C-HIPE $(2 \mathrm{P} 5 \mathrm{HF})$ sample showing both the absence of $\mathrm{Au}^{3+}$ and the presence of metallic gold once reduction process has been applied. 
Table 1

\begin{tabular}{|c|c|c|c|c|}
\hline Sample & $\begin{array}{c}\text { Intrusion } \\
\text { volume } \\
\left(\mathrm{cm}^{3} \mathrm{~g}^{-1}\right)\end{array}$ & $\begin{array}{l}\text { Porosity } \\
\text { (\%) }\end{array}$ & $\begin{array}{l}\text { Skeleton density (g } \\
\qquad \mathrm{cm}^{-3} \text { ) }\end{array}$ & $\begin{array}{l}\text { Bulk density (g } \\
\qquad \mathrm{cm}^{-3} \text { ) }\end{array}$ \\
\hline C-HIPE $(2 \mathrm{PSHF})$ & 6.7 & 83 & 0.7 & 0.12 \\
\hline 3-Au@C-HIPE ${ }_{(2 P 5 H F)}$ & 7.3 & 89 & 1.2 & 0.12 \\
\hline 6-Au@C-HIPE $(2 P 5 H F)$ & 6.6 & 90 & 1.4 & 0.14 \\
\hline 9-Au@C-HIPE & 6.3 & 88 & 1.2 & 0.14 \\
\hline $10-A u @ C-H I P E_{(2 P 5 H F)}$ & 5.6 & 89 & & 0.16 \\
\hline $12-A u @ C-H I P E_{(2 P 5 H F)} *$ & 4.6 & 83 & 1.6 & 0.18 \\
\hline
\end{tabular}


Table 2

\begin{tabular}{ccccc}
\hline Sample & $\begin{array}{c}\text { BET surface } \\
\text { area }\left(\mathbf{m}^{\mathbf{2}} \mathbf{g}^{\mathbf{- 1}}\right)\end{array}$ & $\begin{array}{c}\text { Total pore } \\
\text { volume }\left(\mathbf{c m}^{\mathbf{3}} \mathbf{g}^{\mathbf{- 1}}\right)\end{array}$ & $\begin{array}{c}t \text {-plot surface area } \\
\left(\mathbf{m}^{\mathbf{2}} \mathbf{g}^{\mathbf{- 1}}\right)\end{array}$ \\
\hline External & Meso /Micro \\
\hline C-HIPE $(2 \mathrm{P} 5 \mathrm{HF})$ \\
3-Au@C-HIPE
\end{tabular}


Table 3

\begin{tabular}{|c|c|c|c|c|}
\hline Sample & $\begin{array}{l}\quad \text { Initial } \\
\text { capacity } \\
\left(\mathrm{mA} \mathrm{h} \mathrm{g}^{-1}\right)\end{array}$ & $\begin{array}{c}\text { Initial } \\
\text { capacity } \\
\left(\mathbf{m A ~ h ~} \mathbf{c m}^{-3}\right)\end{array}$ & 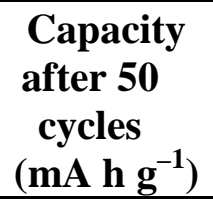 & 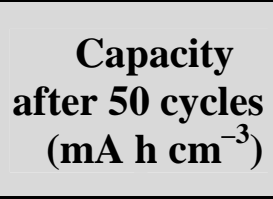 \\
\hline $\mathrm{C}-\mathrm{HIPE}_{(2 \mathrm{P} 5 \mathrm{HF})}$ & 1680 & 202 & 1000 & 150 \\
\hline 3-Au@C-HIPE $(2 \mathrm{P} 5 \mathrm{HF})$ & 966 & 119 & 428 & 53 \\
\hline 6-Au@C-HIPE $(2 \mathrm{P} 5 \mathrm{HF})$ & 1113 & 153 & 527 & 73 \\
\hline 9-Au@C-HIPE $(2 \mathrm{P} 5 \mathrm{HF})$ & 1042 & 146 & 401 & 56 \\
\hline $10-\mathrm{Au} @ \mathrm{C}-\mathrm{HIPE}(2 \mathrm{P} 5 \mathrm{HF})$ & 1156 & 187 & 786 & 127 \\
\hline $12-\mathrm{Au} @ \mathrm{C}-\mathrm{HIPE} \mathrm{(2P5HF}$ & 819 & 147 & 375 & 68 \\
\hline
\end{tabular}


Figure 1

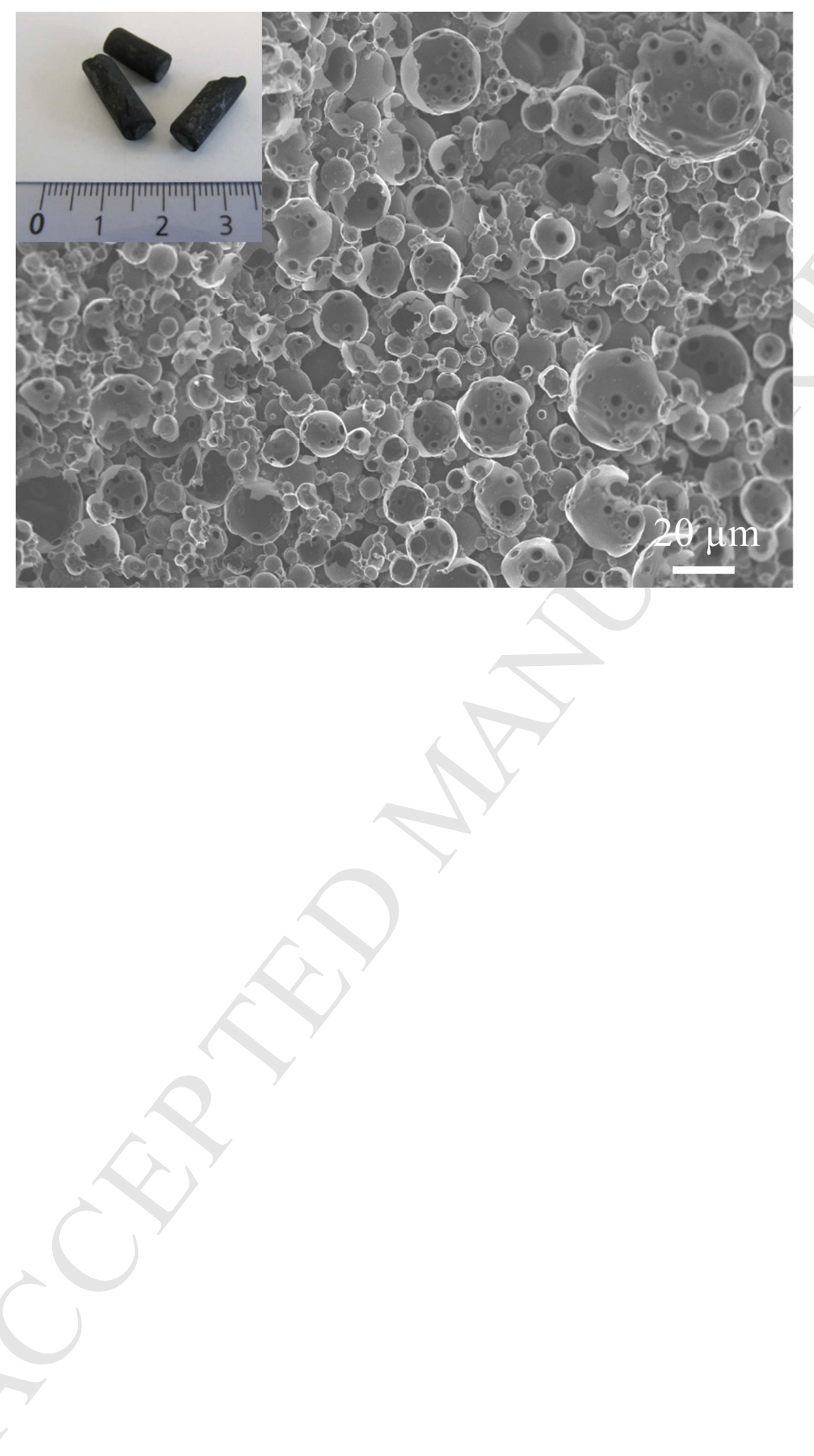


Figure 2
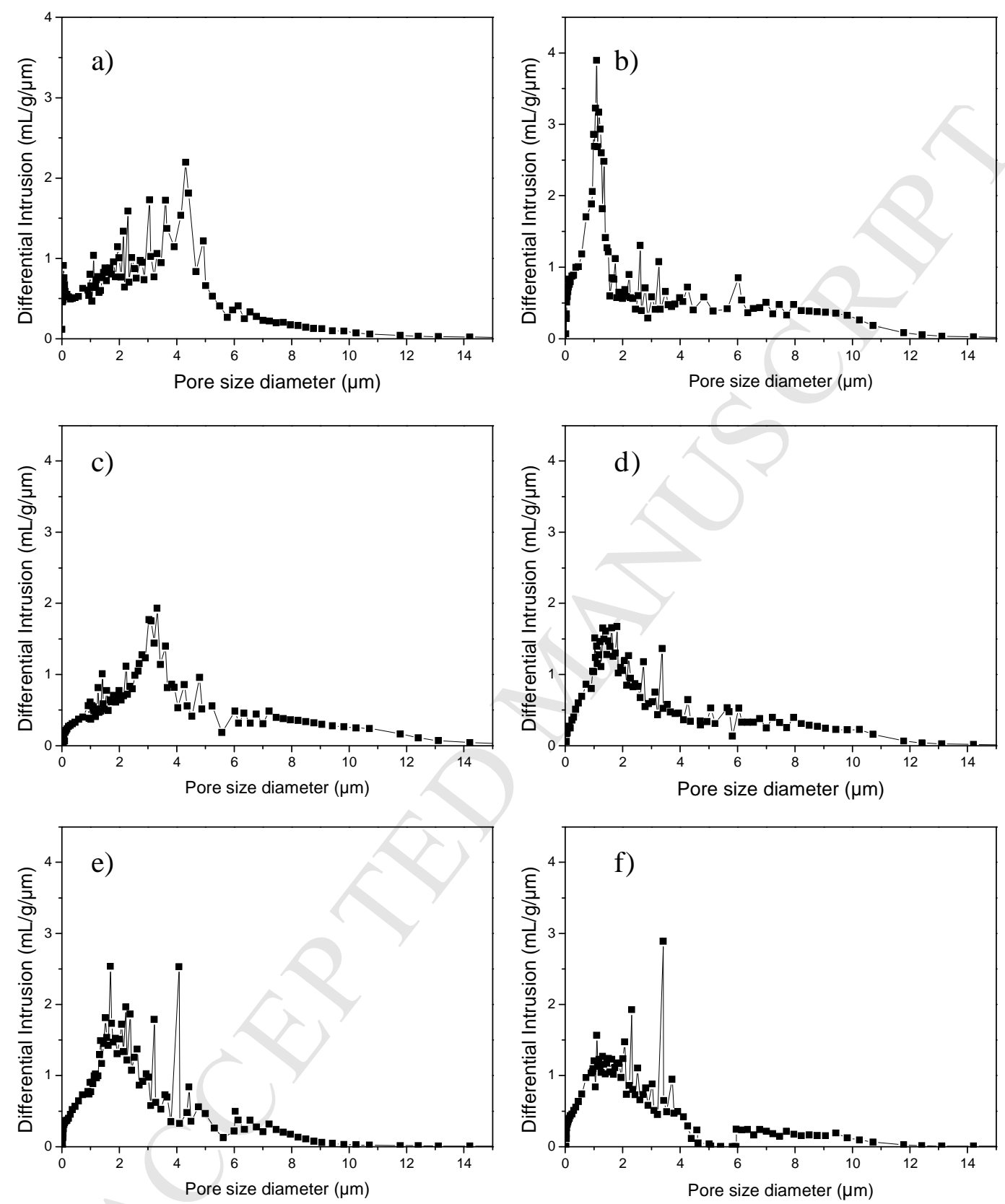
Figure 3
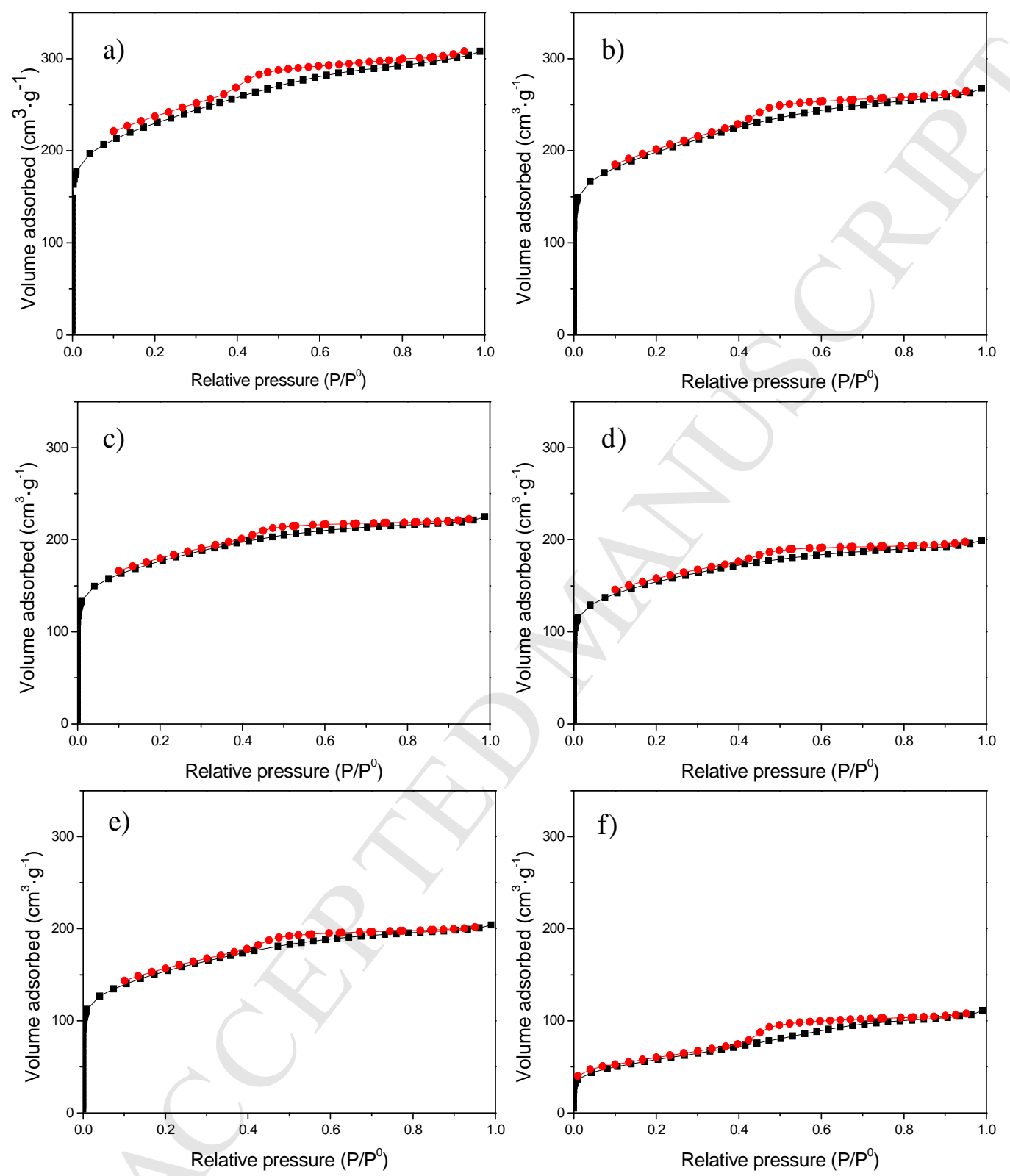
Figure 4
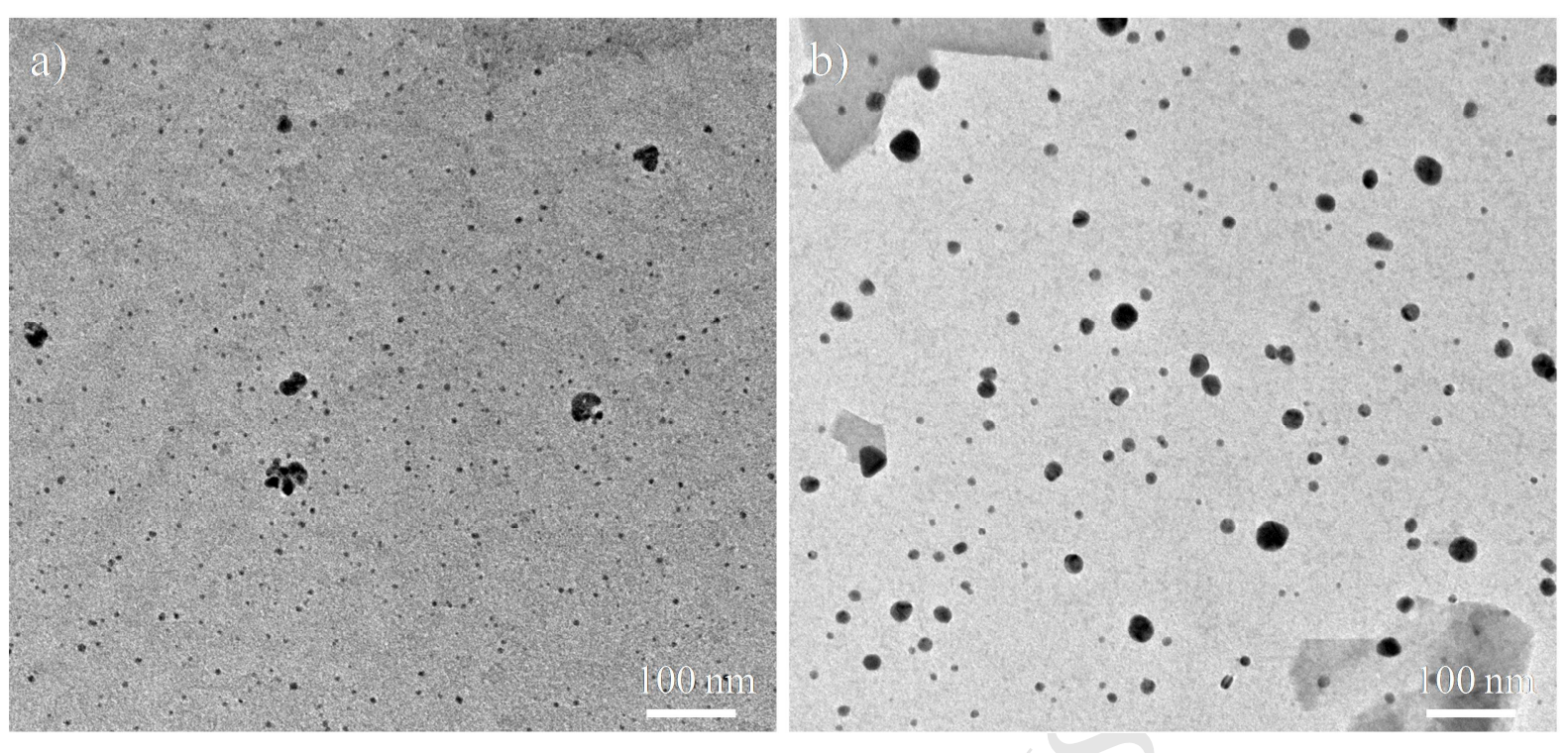
Figure 5
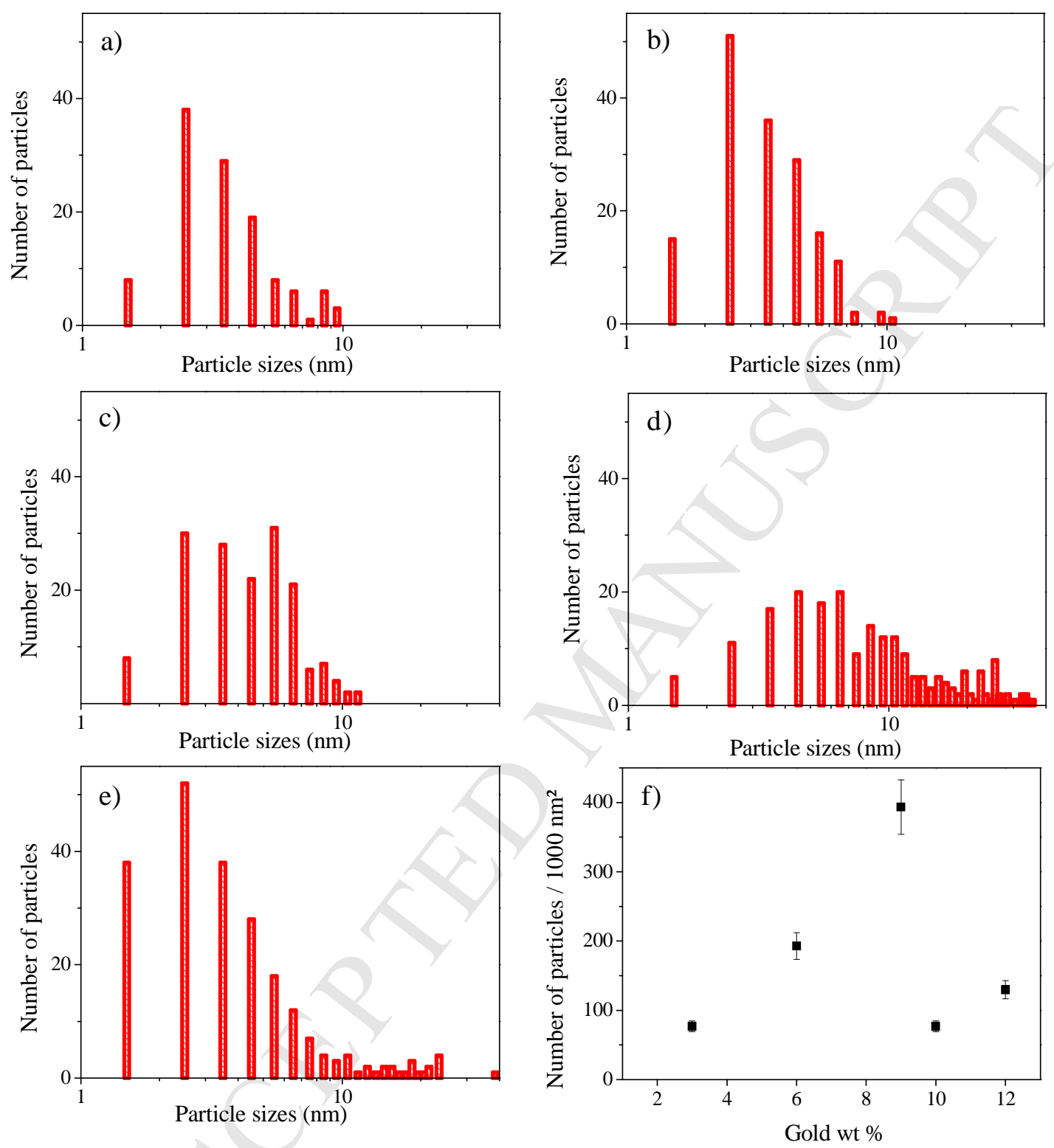
Figure 6
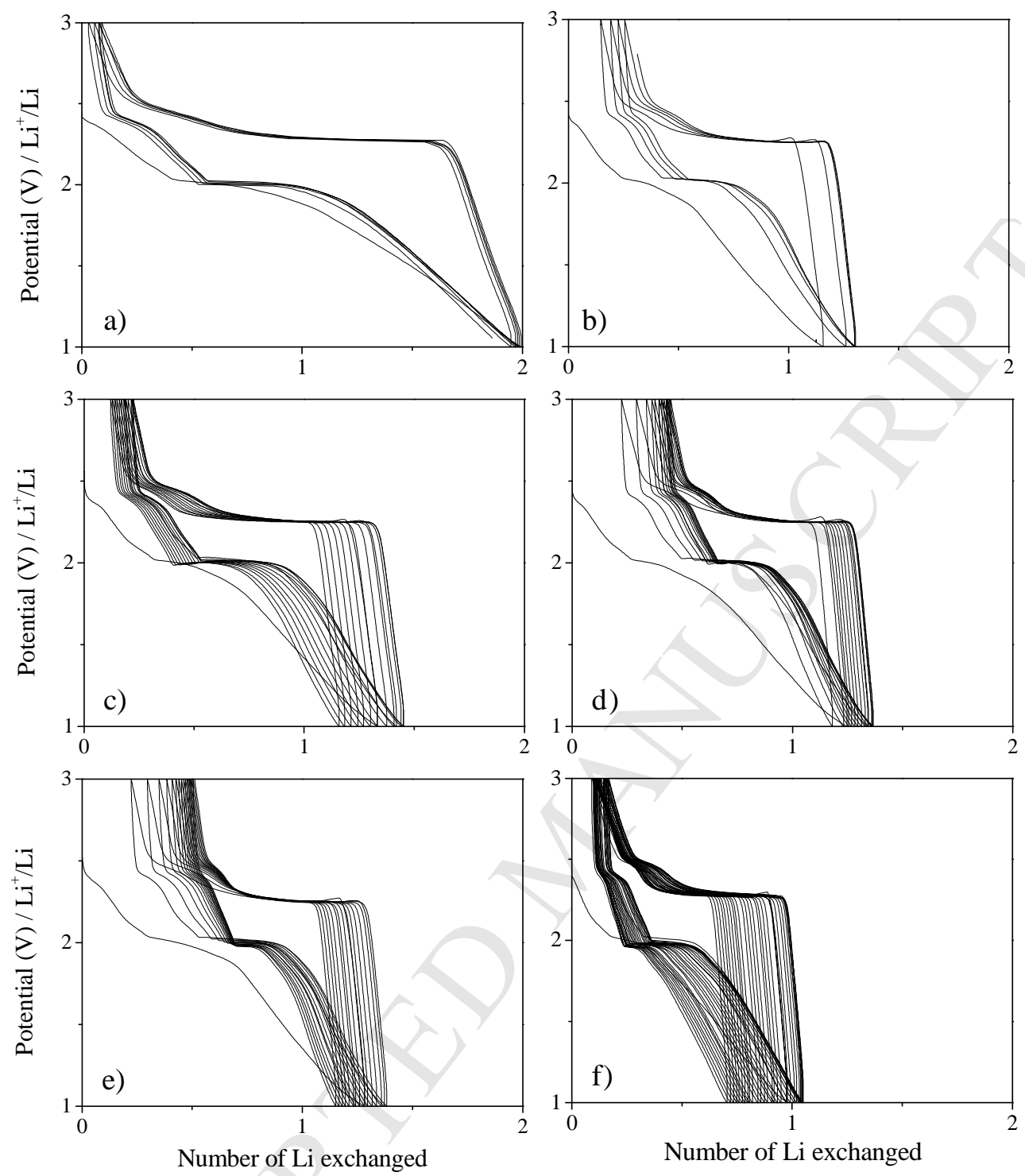
Figure 7
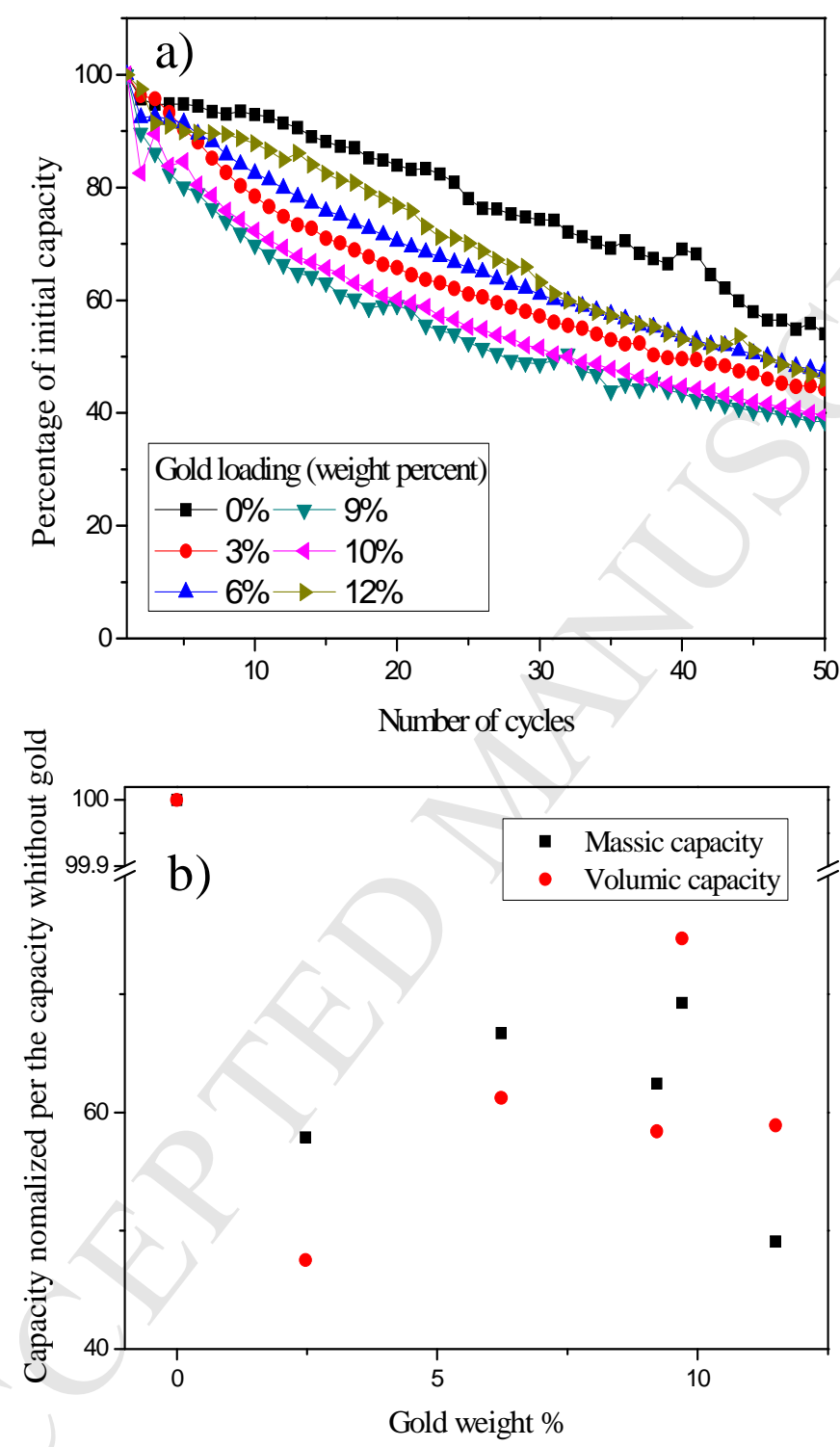


\section{Highlights}

- Carbonaceous foams are synthesized from a hard template method

- Gold nanoparticles have been generated in situ through heterogeneous nucleation

- Native gold nanoparticles are locking the foams mesoscopic voids while favoring $\mathrm{Li}_{2} \mathrm{~S}$ anchoring on their surfaces

- Gold nanoparticles and foams surface area are acting in a partitioning manner toward their restituted capacities when employed as LiS electrodes 